primary bile acid from GCA to GCDCA, a decrease in the amounts of taurine conjugated bile acids and a tendency toward increasing amounts of unconjugated bile acids and secondary bile acids.

Acknowledgments. I express my thanks to Emeritus Prof. Hideo Kato, Prof. Keijiro Yabuta, Dr. Hiroshi Nittono, Department of Pediatrics Juntendo University School of Medicine, and Associate Prof. Birgitta Strandvik, Department of Pediatrics Karolinska Institutet, for constructive criticism of the manuscript, to Mr. Sakae Higashidate of Japan Spectroscopic Co., Ltd. (Jasco) for his assistance on HPLC, to Miss Noriko Furuta of our research laboratory for her assistance, and to Mr. Archibald M. Brown for correcting the English text.

\section{REFERENCES}

1. Arisaka $\mathrm{O} 1981$ Studies on the enterohepatic circulation of bile acids in infancy and childhood. Part 1. Enterohepatic circulation of cholic acid in hepatobiliary disorders of children-especially its application for differential diagnosis of neonatal hepatitis and congenital biliary atresia. Acta Paediatr Jpn. 23:341

2. Arisaka O 1981 Studies on the enterohepatic circulation of bile acids in infancy and childhood. Part 2. The effects of free and conjugated chenodeoxycholic acid on enterohepatic circulation of bile acids-experimental study in rabbits, Acta Paediatr Jpn 23:353

3. Back $P$, Ross K 1973 Identification of $3 \beta$-hydroxy-5-cholenoic acid in human meconium. Hoppe-Seyler's Z Physiol Chem 354:83

4. Barbara L, Lazzari R, Roda A, Aldine R, Festi D, Sama L, Morselli M, Mcollina A, Bazzoli F, Mazzalia G, Roda E 1980 Serum bile acids in newborns and children. Pediatr Res 14:1222

5. Challacombe DN, Edkins S, and Brown GA 1975 Duodenal bile acids in infancy. Arch Dis Child 50:837

6. Danielsson H, and Rutter, W. J. 1968 The metabolism of bile acids in the developing rat liver. Biochemistry 7:346

7. Encranz JC, Sjövall J 1959 On the bile acids in duodenal contents of infants and children. Clin Chem Acta 4:793

8. Hayakawa S, and Samuelsson B 1964 Transformation of cholic acid in vitro by Corynebacterium simplex. J Biol Chem 239:94

9. Heikura S, Similä, S Finni, K Mäentausta O, and Jänne O. 1980 Cholic acid and chenodeoxycholic acid concentration in serum during infancy and childhood. Acta Paediatr Scand 69:659

10. Hofmann, A. F. 1977 The enterohepatic circulation of bile acids in man. Clin Gastroenterol 6:3

11. Holsti $P$ 1956 Experimental cirrhosis of the liver in rabbits induced by gastric instillation of desiccated whole bile. Acta Pathol Microbiol Scand 113: (suppl): 1

12. Holsti $P 1960$ Cirrhosis of the liver induced in rabbits by gastric instillation of 3-monohydroxycholanic acid. Nature, 186:250

13. Jenner RH, and Howard ER 1975 Unsaturated monohydroxy bile acids as a cause of idiopathic obstructive cholangiopathy. Lancet 2:1073

14. Kato H, and Nittono $H 1980$ Toxic effects of bile acids on the hepatobiliary system. In: Cholestasis in Infancy-Its Pathogenesis, Diagnosis and Treatment. Japan Medical Research Foundation, University of Tokyo Press Tokyo

15. Makino I, Nakagawa S, Mashimo K. 1969 Conjugated and unconjugated serum bile acid levels in patients with hepatobiliary diseases. Gastroenterology 56:1033

16. Makino I, Sjövall J, Norman A, and Strandvik B: Excretion of $3 \beta$-hydroxy-5cholenoic and $3 \alpha$-hydroxy-5 $\alpha$-cholanoic acids in urine of infants with biliary atresia. FEBS Lett 15:161

17. Midvedt T, and Norman A 1967 Bile acid transformation by microbial strains belonging to genera found in intestinal contents. Acta Pathol Microbiol Scand 71:629

18. Nittono H 1979 Studies on the toxicity of bile acids in infants. Part 1. Effect of orally fed bile acids on the hepatobiliary system in rabbits.Acta Paediatr Jpn 20:11

19. Nittono H, Niijima S, Ohazama H, Sasaki H, Arisaka O, and Yamada K 1981 Conjugated bile acid levels in gallbladder biles of premature babies, newborn babies and infants.Nippon Shonikagakkai Zasshi 85:224

20. Okuyama S 1979 HPLC analysis of individual bile acids: free, glycine-and taurine-conjugated bile acids. Gastroenterol Jpn 14:129

21. Okuyama S 1981 Analysis of free, glycine-and taurine-conjugated individual bile acids using HPLC and immobilized $3 \alpha$-hydroxysteroid dehydrogenase in column form. Jap J Clin Pathol 29:446

22. Sandberg DH, Sjövall J, Sjövall K, and Turner DA 1965 Measurement of human serum bile acids by gas-liquid chromatography. J Lipid Res 6: 182

23. Sjövall J 1959 The occurrence of $7 \beta$-hydroxylated bile acids in human bile. Acta Chem Scand 13:711

24. Strandvik B 1973 Bile acid metabolism in cholestasis of infancy. Opuseul Med Suppl 29:1

\title{
Exclusively Breast-Fed Healthy Infants Grow Slower than Reference Infants
}

\author{
LEENA SALMENPERÄ, JAAKKO PERHEENTUPA, AND MARTTI A. SIIMES
}

Children's Hospital, University of Helsinki, Helsinki, Finland

\begin{abstract}
We have studied the nutritional adequacy of exclusive breast-feeding by following prospectively the growth and protein nutrition of healthy infants during the 1st yr of life. The number of exclusively breast-fed infants was 116 at the age of 6 months and 36 at 9 months. These infants had slower length velocity after age 3 months than a comparison group of 32 infants who were weaned early and given formula plus solids. As a group, the exclusively breast-fed infants lagged slightly, but progressively, behind in relative length. By 9 months, $45 \%$ of them versus $18 \%$ of the comparison group showed a $>1$ SD decrease in relative length. No such decrease was found in relative weight. Skinfolds and weight for length ${ }^{2}$ index showed that

Received May 21, 1984; accepted November 1, 1984.

Address correspondence to Leena Salmenperä, M.D., Children's Hospital, SF-

This study was supported by grant from Sigrid Juselius Foundation and the Foundation for Paediatric Research, Helsinki, Finland and financial support from Valio Co Ltd, Helsinki, Finland.
\end{abstract} 00290 Helsinki they were heavier for their length than the comparison infants. At 6 and 9 months the calculated protein intake $(0.9 \mathrm{~g} / \mathrm{kg} / \mathrm{day})$ was much less than the recommended amount $(2.0 \mathrm{~g} / \mathrm{kg} /$ day $)$. Serum prealbumin concentration was lower than in the comparison group but this was noted as early as 4 months. No relation was found between the parameters of growth and protein nutrition either individually or in general. Whether the slower growth of the exclusively breast-fed infants represents appropriate physiological growth or whether it indicates nutritional deficiency is not known but we did not find any evidence of protein deficiency. Six infants did, however, show subsequent catch-up growth which could indicate previous malnutrition. (Pediatr Res 19: 307-312, 1985)

\section{Abbreviation}

SDS, standard deviation score, relative length/weight 
Recently there has been a universal trend toward prolonging exclusive breast-feeding. In industrialized countries the aim is to minimize the risk of food induced allergies and infections. In developing countries it is often the availability of breast milk which determines survival. However, little data are available as to what duration of exclusive breast-feeding is nutritionally safe. Studies comparing the growth of exclusively breast-fed and artificially fed infants have given conflicting results (25). An evaluation of the literature on the adequacy of breast-feeding is difficult because the population studied is often racially and/or socioeconomically different from that on which standards are based $(2,13)$. Another problem is the cross-sectional nature of the studies (25). Furthermore, many associated factors have been assumed rather than observed (1). The term "exclusive breastfeeding" has been used for both breast-feeding only without any complements (as we use it) and for breast-feeding plus complements other than milk. Furthermore, the growth of the infants studied may have been influenced by intrauterine deprivation $(1,8)$, especially in developing countries. And lastly, a simple comparison of the mean values for growth parameters may hide individuals or subgroups with a failure to thrive $(1,8,13)$.

Our prospective study evaluates the growth of infants exclusively breast-fed up to the age of 12 months and compares it with that of infants weaned early and/or given complementary foods.

\section{SUBJECTS METHODS}

Subjects, We followed 198 infants born at the Helsinki University Hospital from June to December 1981. Recruitment was done on predetermined days and based on the following criteria: healthy, nonsmoking mother with an uncomplicated pregnancy and delivery; full-term (37.0-42.0 wk of gestation), singleton infant, appropriate for gestational age (15) with Apgar score $\geq 8$, and no evidence of disease by the 3 rd day of life.

This study was approved by the Ethical Committee of the Children's Hospital, University of Helsinki, and is in accord with the Helsinki Declaration.

All but one of the mothers expressed intention to breast-feed for 10 months (i,e, until the end of the maternity leave). The mothers were encouraged to breast-feed exclusively (water drinking was allowed) ad libitum on demand. The number of exclusively breast-fed infants was 116 at 6 months of age, 71 at 7.5 months, 36 at 9 months, and seven at 12 months. The reason for starting complementary feeding before the age of $4-6$ months was that the infant's demand appeared greater than the supply of breast milk. This was decided by the mother in 77 cases and by ourselves in seven, Later, the most common reason was gradual weaning in preparation for the mother's return to work. At 12 months, $33 \%$ of the mothers still nursed for some of the feedings.

The 32 infants weaned completely before 3.5 months were used as a comparison group. An adapted liquid formula was given free of charge to the families. The formula (Valio Co. Ltd, Helsinki, Finland) conformed to the $\mathrm{FAO} / \mathrm{WHO}$ recommendations, except for vitamins $A$ and $D$ which were provided separately. It was given on demand. Fruit and vegetables were introduced at 3 months and cereals and meat at 5 months. The number and amount of new foods were increased gradually. Whole cow's milk was given from 9 months,

Birth size, length of gestation, and midparent height were similar for the artificially fed comparison group and the exclusively breast-fed infants (Table 1). Distribution of social classes, paternal education, and housing conditions were similar for both groups. The mean maternal age $(p<0.01)$ and the frequency of maternal university education $(p<0.05)$ were higher in the breast-fed groups.

Methods, Birth length and weight were measured by the nurses of the maternity unit. All infants were examined, measured, and blood samples taken at $1,2,3,4,6,9$, and 12 months of age and additionally at $5,7.5,10$, and 11 months in the exclusively
Table 1. Background information for the infants exclusively breast-fed for 6 and 9 mo and for the comparison group

\begin{tabular}{llll}
\hline & & \multicolumn{2}{c}{$\begin{array}{c}\text { Exclusively breast-fed } \\
\text { groups }\end{array}$} \\
& $\begin{array}{c}\text { Comparison } \\
\text { group }\end{array}$ & \multicolumn{1}{c}{$6 \mathrm{mo}$} & \multicolumn{1}{c}{$9 \mathrm{mo}$} \\
\hline No. of infants & 32 & 116 & 36 \\
No. of girls/boys & $15 / 17$ & $68 / 48$ & $22 / 14$ \\
Length of gestation (wk) & $40.3 \pm 1.2^{*}$ & $40.1 \pm 1.0$ & $40.2 \pm 1.0$ \\
Birth wt (g) & & & \\
$\quad$ Girls & $3425 \pm 275$ & $3420 \pm 300$ & $3485 \pm 350$ \\
$\quad$ Boys & $3435 \pm 345$ & $3480 \pm 330$ & $3395 \pm 310$ \\
Birth length (cm) & & & \\
$\quad$ Girls & $49.2 \pm 1.5$ & $49.5 \pm 1.4$ & $49.6 \pm 1.5$ \\
$\quad$ Boys & $49.9 \pm 1.4$ & $50.5 \pm 1.3$ & $50.2 \pm 1.1$ \\
Midparent ht (SDS) & $0.15 \pm 0.45$ & $0.17 \pm 0.45$ & $0.18 \pm 0.44$ \\
Maternal age (yr) & $27.7 \pm 3.8$ & $29.4 \pm 4.3$ & $30.6 \pm 3.4$ \\
\hline
\end{tabular}

$*$ Values are mean $\pm \mathrm{SD}$.

breast-fed infants. The measurements were made by one of us (LS) with the help of a specially trained nurse. Length was measured to the nearest $\mathrm{mm}$ with the child lying on a board with a fixed headpiece and movable footpiece, and weight to the nearest $5 \mathrm{~g}$ on an infant scale with the child naked.

The most recent Finnish standards were used for determining relative length and weight in SDS (18). The growth velocities between measurements were calculated by dividing the increments ( $\mathrm{mm}$ or $\mathrm{g}$ ) by the actual time interval (day). The weight for length ${ }^{2}$ index $(5)$ in breast-fed infants was calculated (kg/ $\mathrm{mm}^{2}$ ) as a percentage of the median for the same age and sex in the comparison group. Subscapular and biceps skinfold thicknesses were measured with Bull's calipers.

Peripheral venous blood samples of $2 \mathrm{ml}$ were drawn. Total serum protein was determined by the biuret reaction, transferrin (26), and prealbumin (24) by immunoturbidimetry, $\beta$-lipoprotein by immunodiffusion (Behring), and urea by the ureasephenol-alkaline-hypochlorite method,

All the mothers yielded $10 \mathrm{ml}$ milk before and after each feed to get a pooled milk sample over a $24-\mathrm{h}$ period (23). The protein concentration of the milk sample was determined by a method for lipemic serum (4), and the fat concentration by the Roese Gottlieb-method (14). The volume of milk consumed by the infants was assessed by weighing the infants before and after each feed during a $72-$ h period. This was successful on 79 occasions with 52 individual infants.

Statistical analyses were made using the BMDP software of UCLA (7). The distribution of data was tested for normality using normal probability plots (7). The data for weight velocity, skinfold thickness, and weight for length ${ }^{2}$ index were positively skewed; this was clearly diminished by log transformation. Tests used were $t$ test, simple linear regression and correlation, and analysis of variance for repeated measurements.

\section{RESULTS}

Longitudinal growth, as assessed by length velocity or change in SDS compared with SDS at birth, was slower for the exclusively breast-fed infants even during the first 6 months. The breast-fed infants had higher values in weight for length ${ }^{2}$ index and thicker skinfolds. Their weight velocity was slower after 6 months of age, but no decrease in relative weight (for age) occurred.

Nutrition was evaluated by calculating protein intakes and by several laboratory measurements from the sera of the infants. These did not correlate with the length and weight velocities or with the $\triangle$ SDS for length.

Length velocity, Length velocity was lower in the breast-fed infants during the age periods 3 to 6 months, 6 to 9 months, and 9 to 12 months (Table 2). 
Table 2. Length velocities ( $\mathrm{mm} /$ day) for the comparison group and for the infants breast-fed, exclusively or with complementary food after the age of 6 mo (\% of the comparison groups mean velocity for age and sex)

\begin{tabular}{|c|c|c|c|c|c|c|}
\hline \multirow{3}{*}{$\begin{array}{l}\text { Age } \\
\text { period } \\
(\mathrm{mo})\end{array}$} & \multicolumn{2}{|c|}{$\begin{array}{l}\text { Comparison } \\
\text { group }\end{array}$} & \multicolumn{4}{|c|}{ Breast-fed groups } \\
\hline & \multirow{2}{*}{$\begin{array}{c}\text { Boys } \\
n=17 \\
\text { (mm/day) }\end{array}$} & \multirow{2}{*}{$\begin{array}{c}\text { Girls } \\
n=15 \\
(\mathrm{~mm} / \text { day })\end{array}$} & \multicolumn{2}{|c|}{ Exclusively } & \multicolumn{2}{|c|}{$\begin{array}{c}\text { With } \\
\text { complementary } \\
\text { food }\end{array}$} \\
\hline & & & $n$ & $\%$ & $n$ & $\%$ \\
\hline $0-3$ & $1.24 \pm 0.05^{*}$ & $1.19 \pm 0.05$ & 116 & $99.4 \pm 1.0$ & & \\
\hline $9-12$ & $0.45 \pm 0.03$ & $0.44 \pm 0.02$ & 7 & $87.5 \pm 7.7^{c, d}$ & 45 & $100.1 \pm 2.0$ \\
\hline $0-6$ & $1.00 \pm 0.03$ & $0.94 \pm 0.03$ & 116 & $96.5 \pm 0.7$ & & \\
\hline $3-9$ & $0.63 \pm 0.02$ & $0.57 \pm 0.01$ & 36 & $89.3 \pm 1.9^{b}$ & 45 & $91.7 \pm 1.8$ \\
\hline $6-12$ & $0.47 \pm 0.02$ & $0.45 \pm 0.01$ & 7 & $85.0 \pm 7.4^{c, d}$ & 45 & $97.1 \pm 2.0$ \\
\hline
\end{tabular}

\footnotetext{
* Values are mean $\pm \mathrm{SE}$.

Comparison exclusively breast-fed/comparison groups: ${ }^{a} p<0.01 ;^{b} p<0.05 ;^{c} p<0.001$.

Comparison breast-fed exclusively/with complementary food: ${ }^{d} p<0.05$.
}

Relative length. By the age of 9 months the mean change in SDS for the exclusively breast-fed infants was $-0.87 \mathrm{SD}$, (range -3.4 to $+0.8 \mathrm{SD})$ versus $-0.05 \mathrm{SD}(-1.8$ to $+2.2 \mathrm{SD})$ for the comparison group $(p=0.002)$. There was a decrement of $>1$ SD in $45 \%$ of the breast-fed infants compared with $18 \%$ of the comparison group (Fig. 1). In most cases the decrease was gradual but three of the breast-fed infants and one of the comparison infants had a >1 SD fall during the 6- to 9-month age period.

Effect of complementary feeding on length. If the slower length velocity of the exclusively breast-fed infants was due to nutritional deficiency, then an acceleration of growth might have been expected after complementary feeding was introduced. Complementary feeding did, in fact, reduce the progressive decrease in SDS for length during the 6 to 9 months age period from -0.52 to $-0.32 \mathrm{SD}(p=0.07)$ (Fig. 1); the mean length velocity became similar to that of the comparison group (Table 2), but no general acceleration of length velocity or increase in SDS for length occurred. However, six individual infants showed catch-up growth within 2-6 months (Fig. 2). In three of them the decrease in SDS for length progressed for a further 2-3 months on complementary feeding before the acceleration took place. In most cases there was an acceleration in both length and weight.

Weight velocity. The weight velocity was lower in the breastfed infants during the 6- to 12-month age period (Table 3).

Relative weight. SDS for weight were similar in both groups (Fig. 1).

Weight for length index. The exclusively breast-fed infants were heavier for their length. The index for the exclusively breastfed infants, expressed as a percentage (mean $\pm \mathrm{SE}$ ) of the median of the comparison group, was $103 \pm 0.8 \%(p<0.0001)$ at 6 months, $105 \pm 1.4 \%(p<0.0001)$ at 9 months, and $107 \pm 2.3 \%$ $(p=0.006)$ at 12 months.

Skinfolds. The subcutaneous fat became gradually thicker in the breast-fed infants (Fig. 3). Thus at least part of their higher weight for length ${ }^{2}$ index was due to their greater amount of fat.

Length, weight, and head circumference. In the mean value of absolute length the breast-fed boys and girls diverged progressively downward from the comparison group (Table 4). At age 9 months the mean of boys was $1.4 \mathrm{~cm}$ less for the breast-fed group than for the comparison group $(p=0.09)$. For the girls the difference was $1.0 \mathrm{~cm}(p=0.2)$. No significant differences appeared between the groups in weight or head circumference (data not shown).

Correlation with parental height. Correlations between the midparent height SDS and the infants' length SDS were similar; at 9 months $r=0.44$ for the exclusively breast-fed infants and $r$ $=0.42$ for the others.
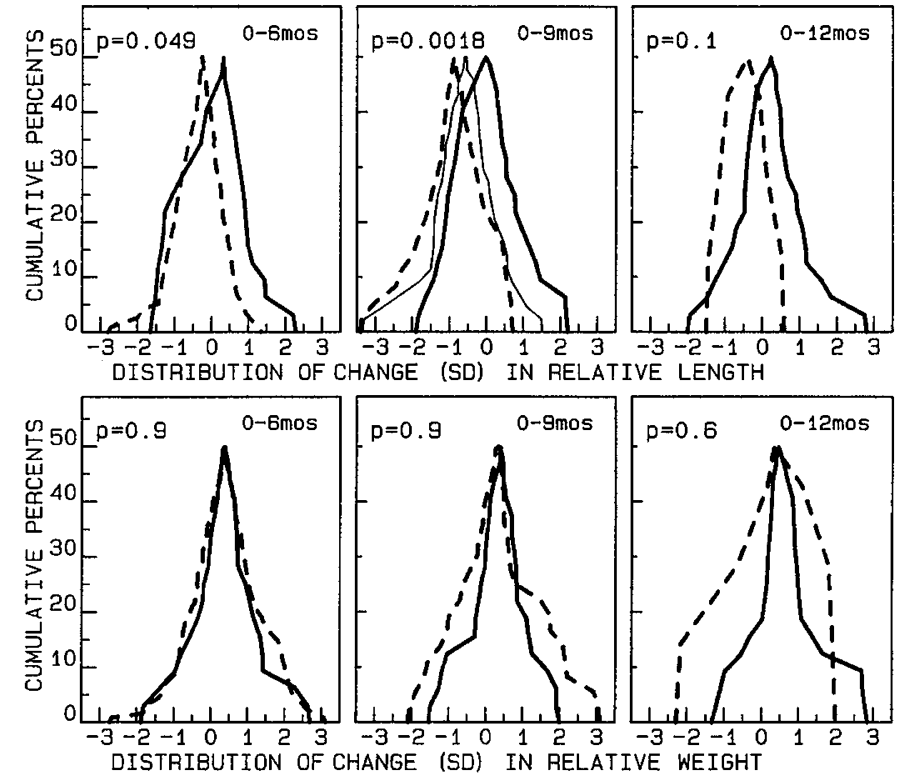

Fig. 1. Changes (SD) in relative length (upper panels) and weight (lower panels) from birth to 6,9 , and 12 months. The number in the comparison group (heavy continuous line) was 32. The number of exclusively breast-fed infants (broken line) was 116 at 6 months, 36 at 9 months, and seven at 12 months. The number of infants fed breast milk + complementary food from the age of 6 months (light continuous line; shown only for length at 9 months) was 45 .

Serum proteins and urea (Table 5). There was no difference in the total serum protein concentration between the groups. However, the concentrations of serum proteins with short half-lives showed somewhat contradictory differences. The prealbumin concentration was lower in the breast-fed infants and remained lower subsequently during complementary feeding. At 6 months 14 of the 116 exclusively breast-fed infants had a prealbumin concentration below the range of the comparison group. At 9 months this proportion was five of 36 infants. In addition, 22 of the 45 infants fed breast-milk and complementary foods had similarly low concentrations. The transferrin concentration was dependent on the iron status and was elevated in the breast-fed infants by 9 months of age (22) although none had anemia. During the first 9 months the $\beta$-lipoprotein concentration increased more in the breast-fed infants. The mean urea concentration of the breast-fed infants was about half that of the 


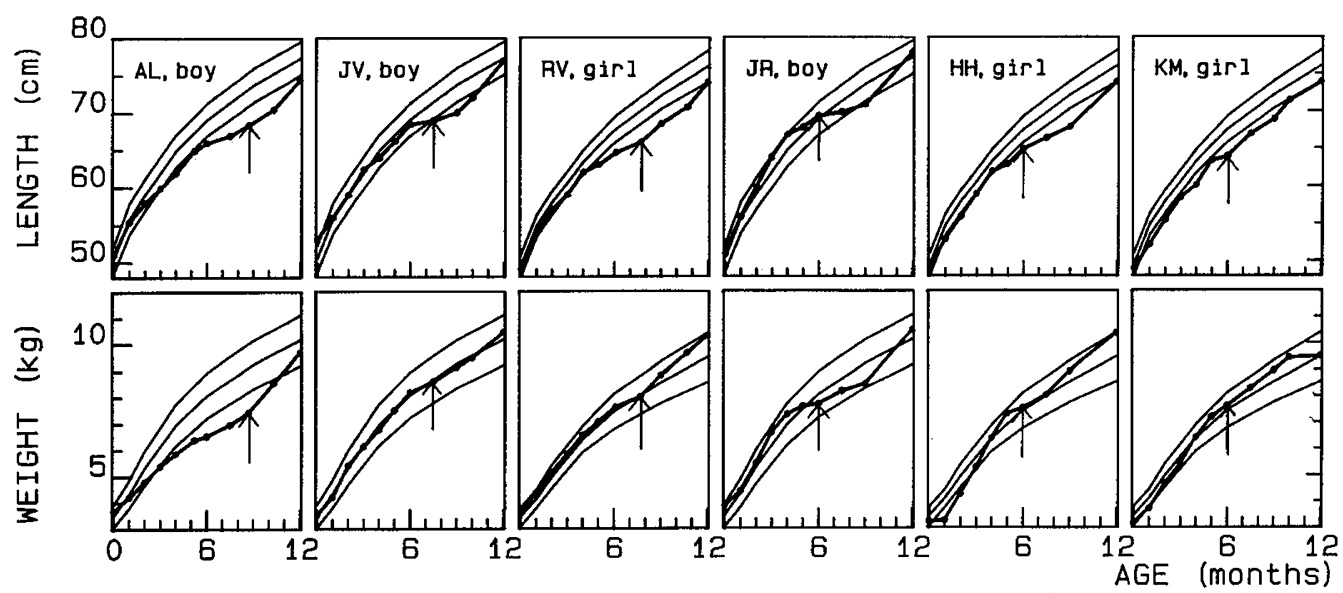

Fig. 2. Individual lengths (upper panel) and weights (lower panel) of the exclusively breast-fed infants who showed catch-up growth after introduction of complementary food (arrows). Three of these six infants had been exclusively breast-fed for 6 months, two for 7.5 months, and one for 9 months. The light lines indicate values of the mean \pm 1 SD for the most recent Finnish standards (18).

Table 3. Wt velocities ( $g /$ day) for the comparison group and for the infants breast-fed, exclusively or with complementary food after the age of $6 \mathrm{mo}$ (\% of the comparison groups mean velocity for age and sex)

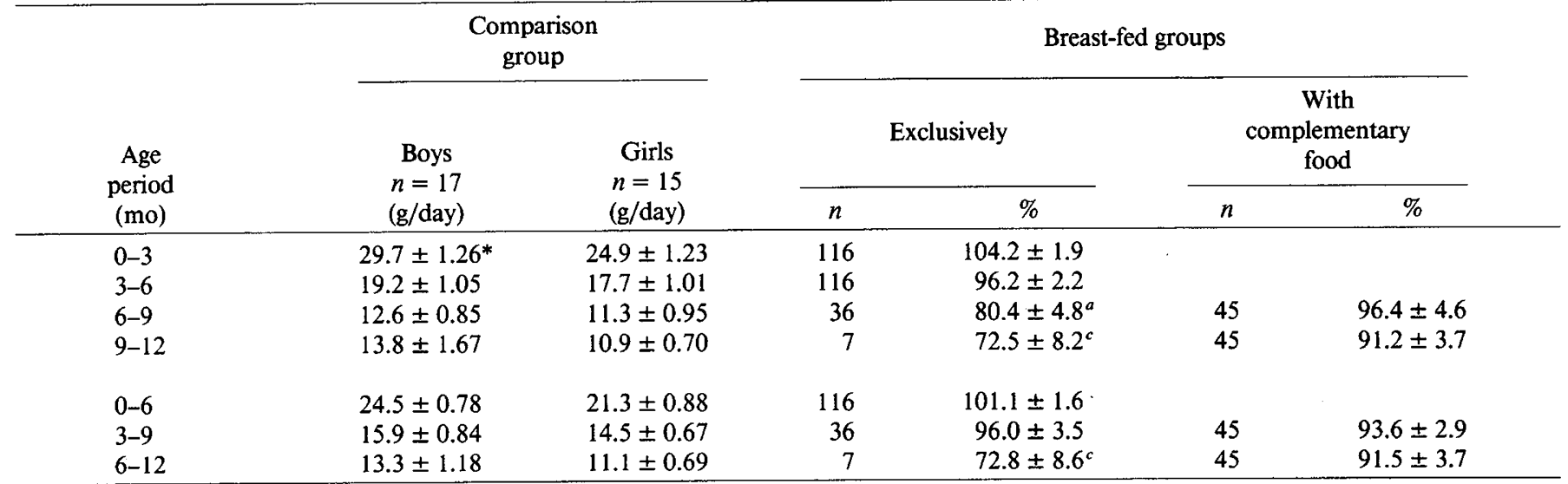

* Values are mean $\pm \mathrm{SE}$.

For symbols see footnote to Table 2 .

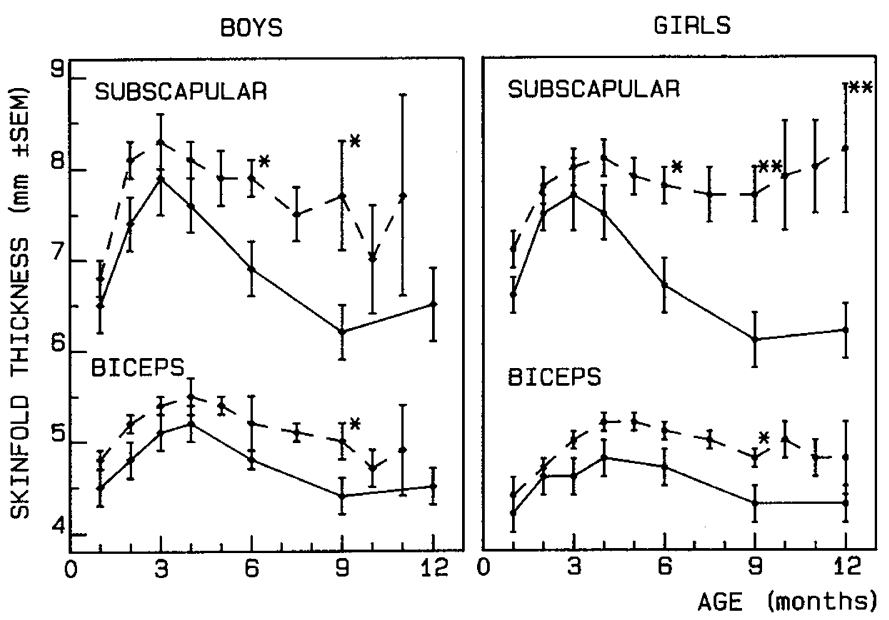

Fig. 3. Mean ( $\pm \mathrm{SE}$ ) skinfold thicknesses in exclusively breast-fed (broken lines) and comparison infants (continuous lines); ${ }^{* *} p<0.01$; $* p<0.05$.

comparison group, and complementary feeding caused a clear increase.

Milk protein and fat (Table 5). The protein concentration of the breast-milk samples decreased with the duration of lactation, the greatest decrease occurring during the first 2 months, from
Table 4. Lengths (cm) for the comparison group and for the infants exclusively breast-fed for 9 mo

\begin{tabular}{cccccc}
\hline & \multicolumn{2}{c}{ Boys } & & \multicolumn{2}{c}{ Girls } \\
\cline { 1 - 1 } \cline { 5 - 6 } & $\begin{array}{c}\text { Comparison } \\
\text { group } \\
(n=17)\end{array}$ & $\begin{array}{c}\text { Breast-fed } \\
\text { group } \\
(n=14)\end{array}$ & $\begin{array}{c}\text { Comparison } \\
\text { group } \\
(n=15)\end{array}$ & $\begin{array}{c}\text { Breast-fed } \\
\text { group } \\
(n=22)\end{array}$ \\
\hline 0 & $49.9 \pm 0.3^{*}$ & $50.2 \pm 0.3$ & $49.2 \pm 0.4$ & $49.6 \pm 0.3$ \\
2 & $58.2 \pm 0.4$ & $58.3 \pm 0.4$ & & $57.4 \pm 0.4$ & $57.6 \pm 0.6$ \\
4 & $64.2 \pm 0.4$ & $64.2 \pm 0.5$ & $62.4 \pm 0.4$ & $62.8 \pm 0.2$ \\
6 & $68.3 \pm 0.4$ & $67.8 \pm 0.4$ & & $66.3 \pm 0.5$ & $66.1 \pm 0.3$ \\
9 & $72.8 \pm 0.6$ & $71.4 \pm 0.5$ & $70.5 \pm 0.5$ & $69.5 \pm 0.4$ \\
\hline
\end{tabular}

$*$ Values are mean $\pm \mathrm{SE}$.

$12.6 \pm 0.3 \mathrm{~g} /$ liter in colostrum to $9.2 \pm 0.2 \mathrm{~g} /$ liter at 2 months $(p<0.0001)$. The protein concentrations in the milk of the individual mothers correlated with one another at different stages of lactation [e.g. the correlation at 2 versus 9 months was $r=$ $0.76(p<0.0001)$, and at 6 versus 9 months $r=0.53$ ( $p<$ $0.0008)$ ]. The protein concentration of the milk correlated with the serum urea concentration $(r=0.42, p=0.005)$, but not with the infant's serum prealbumin concentration. The total fat concentration increased from $26.1 \pm 1.0 \mathrm{~g} /$ liter in colostrum to 39.9 $\pm 3.8 \mathrm{~g} /$ liter at 9 months $(p=0.02)$.

Intakes (Table 6). The daily volume of milk ingested by the exclusively breast-fed infants was unchanged between 4 and 9 
Table 5. Results of serum and milk analyses

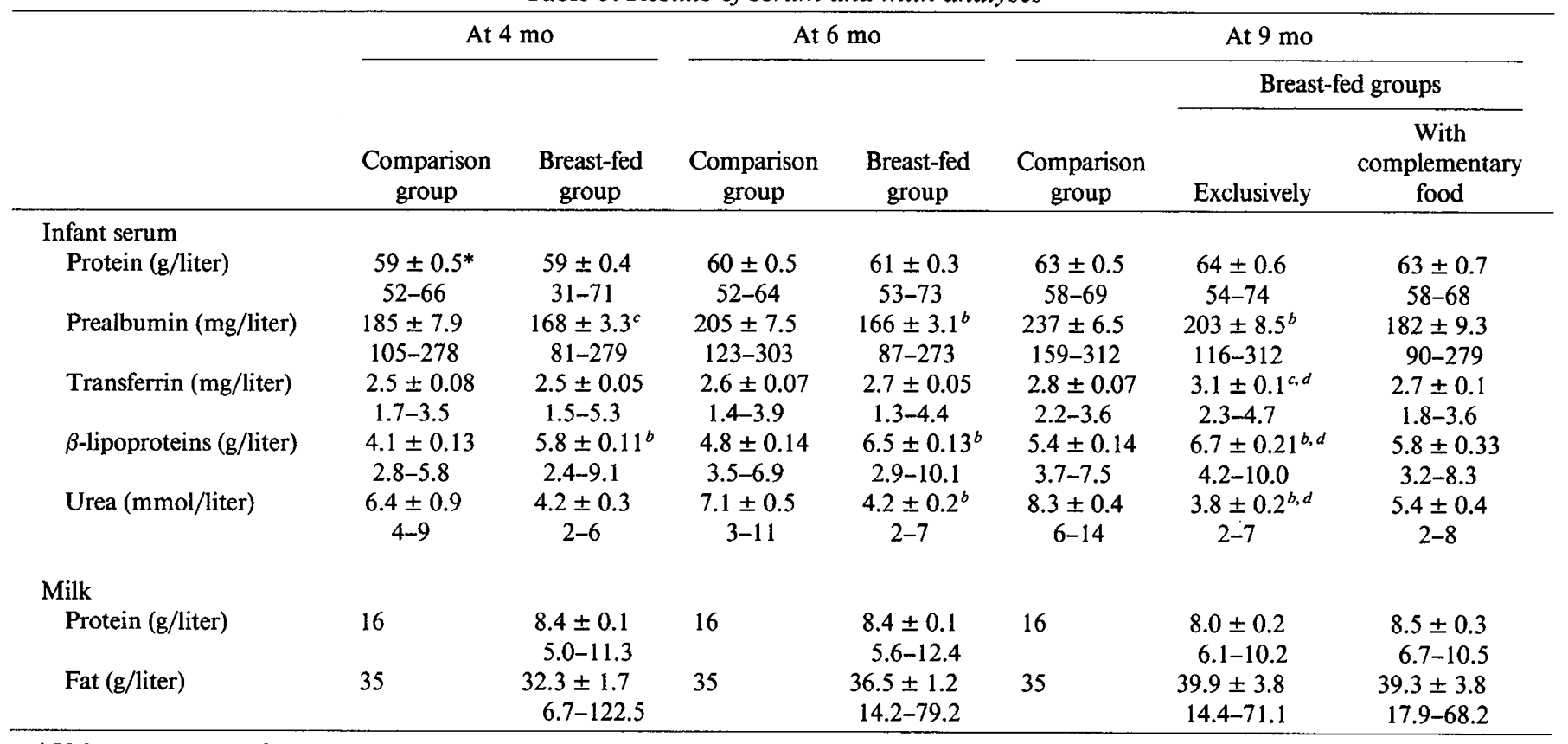

* Values are mean $\pm \mathrm{SE}$ and range.

For symbols see footnote to Table 2 .

Table 6. Calculated intakes during exclusive breast-feeding

\begin{tabular}{ccccc}
\hline Age & $\begin{array}{c}4 \mathrm{mo} \\
(n=12)\end{array}$ & $\begin{array}{c}6 \mathrm{mo} \\
(n=31)\end{array}$ & $\begin{array}{c}9 \mathrm{mo} \\
(n=16)\end{array}$ & $\begin{array}{c}10-12 \mathrm{mo} \\
(n=10 \text { infants, } \\
18 \text { occasions })\end{array}$ \\
\hline Ingested & & & & \\
$\mathrm{ml} /$ day & $790 \pm 40^{*}$ & $800 \pm 20$ & $890 \pm 35$ & $910 \pm 42$ \\
& $510-1120$ & $500-1030$ & $660-1110$ & $740-1060$ \\
$\mathrm{ml} / \mathrm{kg} /$ day & $121 \pm 6$ & $110 \pm 3$ & $105 \pm 5$ & $103 \pm 6$ \\
& $101-169$ & $85-150$ & $76-132$ & $74-123$ \\
Protein intake & & & & \\
$\mathrm{g} /$ day & $7.0 \pm 0.5$ & $6.7 \pm 0.2$ & $7.6 \pm 0.5$ & $7.3 \pm 0.5$ \\
& $3.5-10.4$ & $4.4-9.2$ & $5.1-10.5$ & $4.9-9.8$ \\
$\mathrm{~g} / \mathrm{kg} /$ day & $1.1 \pm 0.07$ & $0.9 \pm 0.03$ & $0.9 \pm 0.06$ & $0.8 \pm 0.06$ \\
& $0.7-1.6$ & $0.6-1.3$ & $0.6-1.3$ & $0.5-1.1$ \\
Fat intake & & & & \\
$\mathrm{g} /$ day & $17 \pm 2$ & $32 \pm 2$ & $35 \pm 7$ & $38 \pm 10$ \\
& $10-23$ & $18-54$ & $9-63$ & $21-64$ \\
$\mathrm{~g} / \mathrm{kg} /$ day & $3 \pm 0.2$ & $4 \pm 0.2$ & $4 \pm 0.2$ & $4.3 \pm 1.1$ \\
& $2-3$ & $3-7$ & $1-8$ & $2-7$ \\
\hline
\end{tabular}

* Values are mean $\pm S E$ and range.

months. The intake of fat increased $(p=0.02)$, whereas the intake of protein was similar at 4 and 9 months.

Correlation between growth and nutrition. Our data do not suggest causal relationships between the parameters of growth and nutrition. No correlation was found among the protein concentration in breast milk, protein intake, or protein intake per kg body weight and growth velocity or changes in SDS for length. Neither did the fat concentration of breast milk or calculated fat intake show any correlation. The consumed milk volumes correlated with weight velocities during the 0 to 6 months $(r=0.92, p=0.006)$ and 6 to 9 months $(r=0.50, p=$ $0.03)$ age periods.

Only two of the 16 infants whose SDS for length decreased by $>1$ SD had serum prealbumin concentrations below the range of the comparison infants at 9 months.

\section{DISCUSSION}

The adequacy of infant nutrition can be evaluated only by relating it to what is considered as the normal growth expectation.
Infancy is a period of rapid changes in growth rates and the pattern of growth is strongly influenced by factors such as sex, birth size, feeding practice, and genetic background (25). Secular changes occur even in industrialized countries. In the present study we concentrated on the influence of feeding practiceexclusive breast-feeding versus formula-feeding according to modern recommendations-in fullterm, appropriate weight for gestational age infants with a uniform, and adequate socioeconomic background.

Our exclusively breast-fed infants grew slower in length than the comparison infants after 3 months of age. The mean length SDS of the breast-fed group decreased continuously; by age 9 months almost half of the breast-fed infants had shown a clear decrease in SDS. This was reflected by a corresponding progressive divergence of the mean values of absolute length downward from the comparison group. The differences did not reach significant levels. Clearly this is to be expected: a change in growth velocity of a group will first manifest as a significant difference in parameters of velocity and only later in parameters of attained size.

The greater weight for length ${ }^{2}$ index and skinfold measurements indicated that the exclusively breast-fed infants did not have any caloric deficiency.

Our breast-fed group was inevitably self-selected and limited to those infants who did not show desire for complementary feeding and whose mothers were satisfied with the exclusive breast-feeding. We cannot exclude the possibility that an infant's inherited tendency to faster growth may have been a reason for earlier need of complementary feeding. However, similar mean values of midparent height in the exclusively breast-fed and comparison groups speak against this possibility. The mothers who had difficulties in establishing breast-feeding were guided at an early stage to formula feeding. We believe that it is impossible to avoid this kind of selection in human studies. It is clear that the need for complementary feeding varies according to individual efficiency in utilizing nutrients, as well as in physical activity. The mothers' success in breast-feeding similarly depends on other factors besides their desire to breast-feed. Despite the general desire for breast-feeding $16 \%$ of the mothers failed to establish or continue it. The majority did succeed and one-third continued partial breast-feeding for more than 12 months. The daily milk 
volumes during exclusive breast-feeding varied greatly among the individual mothers, the mean volume being slightly higher than reported previously (17). The total fat and energy concentration of the milk increased during lactation. Fomon et al. (10) observed that infants older than 49 days were able to increase their volume intake as the calorie concentration of the formula decreased.

By contrast, the protein concentration of the milk decreased, and the mean calculated protein intake per $\mathrm{kg}$ body weight did not increase with age. The breast-fed infants' intake of protein $(0.9 \mathrm{~g} / \mathrm{kg} /$ day $)$ was about half of the amount $(2 \mathrm{~g} / \mathrm{kg} /$ day $)$ recommended by the RDA, during the period of decrease in their growth velocity. Whether this "low" protein intake was adequate for their needs is extremely difficult, if not impossible, to determine. Chan and Waterlow (3) concluded that $1.25 \mathrm{~g} / \mathrm{kg} /$ day of protein is sufficient to support growth at twice the normal rate at the age of about 12 months. Fomon et al. (9) observed that reducing the protein concentration of formula to $9.9 \mathrm{~g} /$ liter caused a decrease in infants' growth velocity before, but not after, the age of 55 days. Factors of infant's metabolism, as well as the quality of protein in the diet, modifies the requirement. Human milk protein appears to be of high biological value.

There are no good anthropometric indices of protein malnutrition. In growing animals protein deficiency results in severe growth failure and relative obesity (16). Our breast-fed infants were heavier for their length than the comparison group. A number of biochemical indices have been proposed for assessing protein nutrition (6). In short-term studies of adults, serum concentration of prealbumin, which has a rapid turnover, was the most sensitive and specific indicator of protein deficiency (21). We therefore anticipated that concentrations of this protein would be informative and, in fact, the prealbumin concentrations were lower in the exclusively breast-fed infants than in the controls. However, this difference was present as early as the age of 4 months when a nutritional disadvantage from exclusive breast-feeding is most unlikely. Furthermore, the prealbumin concentration did not correlate with the parameters of growth or protein intake. Thus the low prealbumin levels associated with breast-feeding appeared unrelated to nutritional status. Serum transferrin levels, by contrast, increased more in the breast-fed infants after the age of 6 months. This phenomenon was related to deficient-iron nutrition. In conclusion, there was no clear indication that either the general or individual decrease in growth velocity was due to inadequate protein nutrition. Nevertheless, the mean growth in length of the breast-fed infants was slower than that of the infants fed with modern formula and solid food. And most importantly, this difference was not due to a subgroup within the breast-fed group but was seen in the group as a whole. The crucial unanswered problem is whether this kind of growth pattern represents appropriate physiological growth or whether it reflects nutritional deficiency, and if so, whether this affects later functional or intellectual development.

If the decrease in length velocity indicates protein malnutrition, then it is the earliest sign of reduced protein nutrition, and decrease in plasma protein concentrations occur later in advancing malnutrition. In human protein-energy malnutrition, growth retardation is an early phenomenon and may be seen more than half a year before any other signs appear (20). The possibility of malnutrition is supported by the increase in growth velocity of some of the exclusively breast-fed infants after starting complementary feeding. This is strong evidence of malnutrition in these particular infants. However, this phenomenon was seen in only a small number of the infants and the temporal relationship with the start of the complementary feeding was variable and often delayed.

The other possible interpretation is that the growth of the breast-fed infants, rather than that of the comparison group, represents appropriate physiological growth. This would imply that increasing the intake of protein or some other nutrient beyond the physiological need causes acceleration of growth, and that our current norms reflect excessive feeding. Such acceleration could be hormonally mediated. At 9 months of age we studied the responses of plasma concentration of nine regulatory peptides to a milk feed. The responses in insulin, gastric inhibitory polypeptide, cholecystokinin, and pancreatic polypeptide were smaller in the exclusively breast-fed infants (to a breast feed) than in the comparison group (to a formula feed) (Salmenperä L, Perheentupa J, Siimes MA, Adrian TE, Blood SR, Aynsley-Green A, unpublished data). Ginsburg et al. (11) have also shown that infants have a smaller plasma insulin response to human milk than to cow milk feed.

Many infants thrive well on exclusive breast-feeding until the age of 9-12 months, but on the population level, it is safer to assume that, even in privileged populations, prolonged exclusive breast-feeding carries a risk of nutritional deficiency in some infants. Accurate monitoring of the velocity of longitudinal growth seems to be the most sensitive, available indicator of adequate nutrition.

\section{REFERENCES}

1. Ahn CH, MacLean WC 1980 Growth of the exclusively breast-fed infant. Am J Clin Nutr 33:183-192

2. Asha Bai PV, Leela M, Subramaniam VR 1980 Adequacy of breast milk for optimal growth of infants. Trop Geogr Med 32:158-161

3. Chan H, Waterlow JC 1966 The protein requirement of infants at the age of about 1 year. $\mathrm{Br} \mathrm{J}$ Nutr 20:775-782

4. Chromy V, Fischer J 1977 Photometric determination of total protein in lipemic sera. Clin Chem 23:754-756

5. Cole TJ, Donnet ML, Stanfield JP 1981 Weight-for-height indices to assess nutritional status-a new index on a slide-rule. Am J Clin Nutr 34:19351943

6. Cooper A, Heird WC 1982 Nutritional assessment of the pediatric patient including the low birth weight infant. Am J Clin Nutr 35:1132-1141

7. Dixon WJ 1981 BMDP Statistical Software 1981, Department of Biomathematics. University of California Press, Berkeley, CA

8. Evans TJ 1978 Growth and milk intake of normal infants. Arch Dis Child 53:749-760

9. Fomon SJ, Thomas LN, Filer LJ Jr, Ziegler EE, Leonard MT 1971 Food consumption and growth of normal infants fed milk-based formulas. Acta Paediatr Scand Suppl 223

10. Fomon SJ, Filer LJ, Jr., Ziegler EE, Bergmann KE, Bergmann RL 1977 Skim milk in infant feeding. Acta Paediatr Scand 66:17-30

11. Ginsburg BE, Lindblad BS, Lundsjö A, Persson B, Zetterström R 1984 Plasma valine and urinary $C$-pepetide in breastfed and artificially fed infants up to 6 months of age. Acta Paediatr Scand 73:213-217

12. Golden M, Waterlow JC, Picou D 1977 The relationship between dietary intake, weight change, nitrogen balance, and protein turnover in man. Am J Clin Nutr 30:1345-1348

13. Hitchcock NE, Gracey M, Owles EN 1981 Growth of healthy breast-fed infants in the first six months. Lancet 2:64-65

14. Horwitz W 1975 Official methods of analysis. In: Association of Official Analytical Chemists. Association of Official Analytical Chemists, Washington, D.C., pp 251-292

15. Largo RH, Wälli R, Duc G, Fanconi A, Prader A 1980 Evaluation of perinatal growth. Helv Paediatr Acta 35:419-436

16. McCance RA 1975 The determinants of growth and form. Modern Prob Paediatr 14:167-78

17. Rowland MGM, Paul AA, Whitehead RG 1981 Lactation and infant nutrition. Br Med Bull 37:77-82

18. Saarinen UM Siimes MA 1979 Role of prolonged breast feeding in infant growth. Acta Paediatr Scand 68:245-250

19. Deleted in proof

20. Scholl TO, Johnston FE, Cravioto J, DeLicardie ER, Lurie DS 1979 The relationship of growth failure (chronic undernutrition) to the prevalence of clinically severe protein-energy malnutrition and to growth retardation in protein-energy malnutrition: Am J Clin Nutr 32:872-878

21. Shetty PS, Watrasiewicz KE, Jung RT, James WPT 1979 Rapid-turnover transport proteins: an index of subclinical protein-energy malnutrition. Lancet 2:230-232

22. Siimes MA, Salmenperä L, Perheentupa J 1984 Exclusive breast-feeding for 9 months: Risk of iron deficiency. J Pediatr 104:196-199

23. Tarjän R, Krámer M, Szöke K, Lindner K 1963 The effect of different factors on the composition of human milk and its variation. I. The effect of vitaminrich foods on the composition of human milk. Nutr Diet 5:12-29

24. Teppo AM, and Maury CPJ 1983 Serum prealbumin, transferrin and immunoglobulins in fatty liver, alcoholic cirrhosis and primary biliary cirrhosis. Clin Chim Acta 129:279-286

25. Underwood BA, Hofvander Y 1982 Appropriate timing for complementary feeding of the breast-fed infant. A review. Acta Paediatr Scand Suppl 294:1 32

26. van Munster PJJ, Hoelen GEJM, Samwel-Mantingh M, Holtman-van Meurs, M 1977 Transferrin immunoturbidimetric analyses with automated individual blank compensation. Clin Chim Acta 76:377-388 